\title{
Post Bioremediation Effect on Soil Fertility using Substrate from Livestock Byproduct
}

\author{
Ekenwosu J. U. \\ Department of Animal and Environmental Biology, Faculty of Science, Imo State University Owerri \\ * Corresponding author email: josephekenwosu@ gmail.com
}

Received: 11 February 2019 / Revised: 10 April 2019 / Accepted: 10 May 2019 / Published: 24 May 2019

\begin{abstract}
The purpose of this study was to examine data obtained from soil physicochemical properties before and after initiation of bioremediation using liquid manure as a nutrient source. Bioremediation was initiated by stimulating autochthonous microorganisms present in soil rhizosphere while remediation was determined by soil physicochemical status after nutrient amendment. Rhizomes of turmeric were planted in soil treated with liquid manure and control in a randomized complete block design (RCBD) with three replications. Data generated from soil physicochemical parameters both in the laboratory and field were analyzed before and after treatment/cultivation. The study showed that treated soil increased total nitrogen, organic matter, organic carbon, exchangeable potassium, cation exchange capacity (CEC), calcium and exchangeable phosphorus. On the other hand, it decreased soil acidity, $\mathrm{pH}$ and exchangeable aluminium. There were no observable differences in magnesium concentration. Soil texture had more sand and a corresponding decline in silt and clay. Findings in this study revealed that soil that benefitted from treatment option is statistically significant at 0.05 p-level.
\end{abstract}

Keywords: Soil remediation, Autochthonous microorganisms, Liquid manure, Physicochemical properties

\section{Introduction}

Many countries are faced with environmental challenges because of anthropogenic activities such as gas flaring, oil exploration and production, agricultural activities, pollution etc. Agriculture being an integral part of man right from pre-historic times can cause pockets of environmental devastation if not properly controlled and when this happens, soil loses its ability to supply necessary nutrients needed for plant growth and sustainability of living organisms within the rhizophere. However, soil remediation can be achieved using biological techniques (bioremediation). There have been several definitions of bioremediation but [1] defined it as biological response to environmental abuse. In addition, [2] defined it as a technology for removing pollutants from the environment thus restoring the natural ecosystem. This technology is believed to be the solution in returning the environment back to its original condition because it is cheap and ecofriendly [3]. Bioremediation technology can be done "ex situ" or "in situ" depending on some criteria. "In situ" bioremediation has minimal site disruption and can be integrated with other treatment methods for optimum result however before choosing any remediation technique, the location, depth and degree of pollution, type of environment and nature of pollutants are some factors that should be considered [4]. Bioremediation processes depend on the simplicity and effectiveness of microorganisms in restoring the ecosystem to its natural state when compared to other technologies [5]. This technology has made it possible to cultivate land previously considered as unsuitable. Bioremediation functions basically on mineralization of nutrient sources or by transforming complex contaminants to simple non-toxic compounds by microorganisms [6]. Although there are a variety of bioremediation 
techniques, most studies on remediation often focused on hydrocarbon pollution of soil and ground water. A typical example is the widely reported success of Exxon Valdezoil spill cleanup using bioremediation technology [7]. However, studies on remediating sites polluted by nonhydrocarbon pollutants using biological processes have reached advanced stage. [8] successfully isolated Dehalococcoides (anaerobic bacteria living in the soil which has the capacity to biodegrade contaminants with chlorine atoms such as Perchloroethane (PCE) and Trichloroethane (TCE) to non-toxic ethane). PCE when released into the environment become long term groundwater threat and is carcinogenic causing damage to kidneys, livers, lungs and central nervous system. However, it is possible that there may be bioremediation technologies which might as well be ecofriendly, efficient and economical when remediating sites [9]. Thus, there is now increasing interest in the use of substrates from organic source to promote bacterial activities during bioremediation.

Microorganisms depend on nutrients to provide energy needed for their metabolic activities and degradation is a precursor towards achieving this. Although soil autochthonous microorganisms are crucial in solving issues associated with bioremediation, there must be suitable environmental conditions for them to thrive [10]. Inasmuch as these microbes are present in soil, they may not necessarily be there in the numbers required for bioremediation to take place. On the other hand, the available ones need to be stimulated by substrate to ensure their survival in the environment. It is therefore safe to conclude that microbial bioremediation technology aimed at remediating soil basically target stimulation of indigenous soil microorganisms (biostimulation) or augmentation of indigenous soil microorganisms (bioaugumentation) to facilitate the process of remediating contaminated ecosystem to a pre-pollution state [11]. Hence, studies on nutrient amendment to boost soil microbial metabolic activities have provided irrefutable evidence that it is an effective approach to improving soil fertility and crop growth as reported by [12]. To this end, this study was carried out to examine data obtained from soil physicochemical properties before and after initiation of bioremediation using liquid manure as nutrient source.

\section{Materials and Methods}

This study was carried out in the experimental farm, Faculty of Agriculture/Veterinary Medicine, Imo State University Owerri located at latitude $5^{\circ} 30^{\prime} 13^{\prime \prime} \mathrm{N}$ and longitude $7^{\circ} 2^{\prime} 37^{\prime \prime} \mathrm{E}$ south-east Nigeria. According to Köppen's climate classification, the study region has highest average temperature of $27.9^{\circ} \mathrm{C}$ in March while August remains the coldest month of the year with an average temperature of $25.0^{\circ} \mathrm{C}$ [13]. Field experiments were conducted during 2017 planting season (March 2017 to February 2018). The area was selected because it can easily be monitored and controlled. Agronomic practices were applied according to established guidelines outlined by International Institute of Tropical Agriculture IITA [14] prior to cultivation. Beds were prepared $15 \mathrm{~cm}$ in height with $30 \mathrm{~cm}$ spacing between them. Length and width of beds were $270 \mathrm{~cm}$ and $60 \mathrm{~cm}$ respectively. Turmeric rhizome was planted at a depth of $7.5 \mathrm{~cm}-8.0 \mathrm{~cm}$ while maintaining $40 \mathrm{~cm} \times 30 \mathrm{~cm}$ spacing between and within the rows. Beds were tagged to indicate type of treatment applied on them. Liquid manure was evenly applied to beds tagged (M) while control was tagged (C). Treatments were assigned to beds in a randomized complete block design (RCBD) with three replications. Tim Marshall's method was used in preparing the substrate. This method basically allows microbes to anaerobically act on a mixture of water and cow dung while in a container [15].

\subsection{Laboratory Analysis of Soil Samples}

$500 \mathrm{~g}$ soil samples were randomly collected at 0 $40 \mathrm{~cm}$ below ground surface with a stainless-steel cylindrical auger to test for physicochemical properties. Samples were collected before and after nutrient amendment and then transported in a black plastic bag to the laboratory and analyzed for physicochemical characteristics using methods outlined by International Institute of Tropical Agriculture IITA. Texture, $\mathrm{pH}$, organic matter content, organic carbon, total nitrogen, available phosphorus, exchangeable 
Ekenwosu J. U., Int. Ann. Sci.; Vol. 7, Issue 1, pp: 33-37, 2019

potassium, calcium, magnesium, phosphorus, exchangeable acid and cation exchange capacity were measured. Soil $\mathrm{pH}$ was determined by electrometric method. Organic carbon was determined using procedures described by Walkey Black. Soil texture was determined by mechanical sieve shaker. Organic matter was obtained by determination of ash content. Exchangeable cations of $\mathrm{Ca}^{2+}$ and $\mathrm{Mg}^{2+}$ were determined by atomic absorption spectrophotometry (AAS). Exchangeable cation of $\mathrm{K}^{+}$was determined by flame emission spectrophotometry (FES). Available phosphorus $\left(\mathrm{P}_{2} \mathrm{O}_{5}\right)$ in soil was determined by Lancaster method. Total nitrogen content was determined by Micro-Kjeldahl method. Aluminium was determined by colorimetric platinum cobalt method. Soil acidity $\left(\mathrm{H}^{+}\right)$was determined by percolation method while CEC was determined by ammonium saturation.

\subsection{Statistical Analysis}

Data generated from field and laboratory was statistically analyzed using Analysis of Variance (ANOVA) while Least Significant Difference (LSD) was used to test for any significant difference among treatments.

\section{Results and Discussion}

The effects of treatments on soil physicochemical parameters are shown in Table 1. This study revealed that soil that benefitted from treatment recorded a decrease in $\mathrm{pH}$. Soil sample from manure treatment recorded a decrease in $\mathrm{pH}$ from $6.29 \pm 004$ to $6.15 \pm 0.01$. This is in agreement with results of several other studies that have shown that organic manure decrease soil $\mathrm{pH}$ if continuously used for a long period of time. [16] reported that soil $\mathrm{pH}$ decreased by $0.3-$ 0.7 after 11 years of organic manure treatment (with livestock byproducts). Also, the $\mathrm{pH}$ range recorded in this study is optimum for bioremediation to take place as reported by [17] who opined that microorganisms requires $\mathrm{pH}$ within the range of 5.5-8.8 for effective metabolic activities. There was significant increase in organic matter content in soil from $2.50 \pm 0.03$ to $7.80 \pm 01$. The build-up in cation exchange capacity (CEC) status in the soil was observable as it increased from $1.50 \pm 0.01$ before treatment to $2.52 \pm 0.01$ after treatment. The CEC is related to nature, quality and organic matter contents of soil as reported by [18]. Hence, the high organic matter content recorded in this study could be responsible for the CEC value obtained.

Table 1: Effects of treatments on soil physicochemical parameters before treatment/cultivation and after treatment/cultivation

\begin{tabular}{|c|c|c|c|}
\hline \multirow[t]{2}{*}{ Parameters } & \multirow[t]{2}{*}{ Before Treatment/Cultivation } & \multicolumn{2}{|c|}{ After Treatment/Cultivation } \\
\hline & & Manure & Control \\
\hline \multicolumn{4}{|l|}{ Texture } \\
\hline Sand $(\%)$ & $83.5 \pm 0.29$ & $94.9 \pm 0.57$ & $98.7 \pm 0.17$ \\
\hline Silt $(\%)$ & $3.83 \pm 0.17$ & $2.76 \pm 0.30$ & $1.25 \pm 0.03$ \\
\hline Clay $(\%)$ & $11.7 \pm 0.17$ & $0.60 \pm 0.01$ & $0.21 \pm 0.01$ \\
\hline \multicolumn{4}{|l|}{ Chemical Properties } \\
\hline $\mathrm{pH}\left(\mathrm{H}_{2} \mathrm{O}\right)$ & $6.29 \pm 0.04$ & $6.15 \pm 0.01$ & $6.20 \pm 0.01$ \\
\hline Organic carbon $(\%)$ & $1.41 \pm 0.03$ & $11.6 \pm 0.02$ & $9.42 \pm 0.01$ \\
\hline Organic matter $(\%)$ & $2.50 \pm 0.03$ & $7.80 \pm 0.01$ & $5.02 \pm 0.01$ \\
\hline $\mathrm{Al}^{3+}(\mathrm{cmol} / 100 \mathrm{~g}$ soil $)$ & $2.37 \pm 0.01$ & $1.56 \pm 0.01$ & $1.63 \pm 0.01$ \\
\hline Total N (\%) & $0.37 \pm 0.27$ & $0.40 \pm 0.01$ & $0.39 \pm 0.01$ \\
\hline $\mathrm{Ca}^{2+}(\mathrm{cmol} / 100 \mathrm{~g}$ soil $)$ & $2.38 \pm 0.01$ & $3.33 \pm 0.02$ & $3.00 \pm 0.03$ \\
\hline $\mathrm{Mg}^{2+}(\mathrm{cmol} / 100 \mathrm{~g}$ soil $)$ & $0.59 \pm 0.00$ & $0.59 \pm 0.00$ & $0.59 \pm 0.00$ \\
\hline $\mathrm{K}^{+}(\mathrm{cmol} / 100 \mathrm{~g}$ soil $)$ & $0.06 \pm 0.00$ & $23.3 \pm 0.02$ & $8.31 \pm 0.01$ \\
\hline $\mathrm{CEC}(\mathrm{cmol} / \mathrm{kg}$ soil $)$ & $1.50 \pm 0.01$ & $2.52 \pm 0.01$ & $2.04 \pm 0.03$ \\
\hline Acidity & $0.69 \pm 0.01$ & $0.29 \pm 0.10$ & $0.35 \pm 0.01$ \\
\hline $\mathrm{P}(\mathrm{ppm})$ & $5.86 \pm 0.14$ & $8.18 \pm 0.00$ & $6.90 \pm 0.01$ \\
\hline
\end{tabular}


Study revealed that there was reduction in soil acidity from $0.69 \pm 0.01$ before treatment to $0.29 \pm 0.10$ after manure treatment. This reduction may be connected to the complex chemical reactions of organic matter in the soil. Total nitrogen content increased in soil from $0.37 \pm 0.27$ to $0.40 \pm 0.01$ after manure treatment. This may be due to the fact that manure gradually releases nitrogen to the soil. $\mathrm{P}$ status in soil significantly increased according to this study from $5.86 \pm 0.14$ before treatment to $8.18 \pm 0.00$ after manure treatment. This result is in agreement with previous study by [19]. There was significant increase in $\mathrm{K}$ in soil samples from $0.06 \pm 0.01$ before treatment to $23.3 \pm 0.02$ after manure treatment. Similar findings were also reported by [19]. $\mathrm{Al}^{3+}$ concentrations decreased in soil that benefitted from treatment with values ranging from $2.37 \pm 0.01$ before treatment to $1.56 \pm 001$ after manure treatment. This may be because of the involvement of manure in degradation reaction as reported by [20]. Study revealed that organic carbon significantly increased in soil from $1.41 \pm 0.03$ before treatment to $11.6 \pm 0.02$ after treatment. This increase may be attributed to addition of manure which invariably increases organic matter content in soil. Effect of $\mathrm{Mg}^{2+}$ was clear as there were no observable differences in magnesium concentration. Study showed that calcium concentration in soil increased from $2.38 \pm 0.01$ before treatment to $3.33 \pm 002$ after treatment. The possible explanation for this could be that there is a strong correlation between organic matter content and soils preference for $\mathrm{Ca}$ as observed by [21]. Study showed soil texture had more sand and a corresponding decline in silt and clay.

\section{Conclusions}

The bioremediation technology used in this study was a simple, effective and environmentally friendly approach whose biostimulant availability is compatible to the environment and is mainly of organic origin. Substrate from organic manure used as bioremediation agent has proven to be effective and reliable due to its ecofriendly nature and ability to restore soil fertility. Study showed statistically significant differences were observed in soil. Generally, organic manure has positive influence on soil texture and structure, better water holding capacity and drainage. This study concludes that while it is feasible to restore polluted ecosystem back to its original state, it will only be possible if the right bioremediation technology is applied and the political initiatives to regulate agricultural activities are undertaken.

\section{Declaration}

\subsection{Acknowledgements}

Author acknowledges with gratitude contributions of Prof P.U. Okorie, Dr. A.A. Amaechi and Dr. C.I. Ikpeama in the department of Animal and Environmental Biology, Imo State University Owerri. This research did not receive any grant from funding agencies either in the public or private sector.

\subsection{Conflict of Interest}

The author declares there is no conflict of interest regarding this publication.

\section{How to Cite this Article:}

J. Ekenwosu, "Post Bioremediation Effect on Soil Fertility using Substrate from Livestock Byproduct”, Int. Ann. Sci., vol. 7, no. 1, pp. 33-37, May 2019. doi: 10.21467/ias.7.1.33-37

\section{References}

[1] G. Hammer, "Bioremediation: a response to gross environmental abuse". Trends in Biotechnology, 11, 8, pp 317-319, 1993.

[2] C.S. Sasikumar and T. Papinazath, "Environmental management: bioremediation of polluted environment". Proceedings of the Third International Conference on Environmental and Health, Chennai, India, pp $465-$ 469, 2003.

[3] V.S. Millioli, E.L.C Servulo, L.G.S Sobral and D.D DeCarvalho, "Bioremedation of crude bearing soil: Evaluating the effect of Rhamnnolipid addition to soil toxicity and to crude oil biodegradation efficiency". Global Nest Journal. 11, 2, pp 181-188, 2009.

[4] C.C. Azubuike, C.B. Chikere and G.C. Okpokwasili, "Bioremediation techniques-classification based on site of application: principles, advantages, limitations and prospects", World Journal of Microbiology and Biotechnology, 32, p 180, 2016.

[5] M.I. Jeremiah, "Bioremediation of oil contaminated soil using emulsifier (liquid soap), NPK fertilizer and microbial (Bacillus sp) treatment." MSc thesis, Ahmadu Bello University, Zaria Nigeria, 2008.

[6] N. Das and C. Preethy, "Microbial degradation of petroleum hydrocarbon contaminants: An Overview". 
Biotechnology Research International 2011, pp 13, 2010.

[7] K. Lee and F.X. Merlin, "Bioremediation of Oil on Shoreline Environments: Development of Techniques and Guidelines, Pure and Applied Chemistry, 71, 1, pp 161-171, 1999.

[8] L. Alvarez-Cohen, "A system Approach to Bioremediation" UC Berkeley Superfund Research Programme.https://www.youtube.com/watch?v=YJURa hqtkYY

[9] L.V. Pavel and M. Gavrilescu, "Overview of ex situ decontamination techniques for soil clean up". Environmental Engineering and Management Journal, 7, 6, pp 815-834, 2008.

[10] J.P. Verna and D.K. Jaiswal, "Book review advances in biodegradation and bioremediation of industrial waste". Frontiers in Microbiology 6, pp 1-2, 2016.

[11] W.F.M. Röling, M.G. Milner, D.M. Jones, K. Lee, F. Daniel, R.J.P Swannell and I.M. Head, "Robust hydrocarbon degradation and dynamics of bacterial communities during nutrient-enhanced oil spill bioremediation". Applied Environmental Microbiology, 68, 11, pp 5537-5548, 2002.

[12] M.Z.U. Kamal and M.N. Yousuf, "Effect of Organic Manures on Growth, Rhizome Yield and Quality Attributes of Turmeric (Curcuma longa L.)". The Agriculturist, 10, 1, 16-22, 2012.

[13] Available at: https://en.climatedata.org/africa/nigeria/imo/owerri-889379/

[14] International Institute of Tropical Agriculture, "Selected methods in Soil and Plant Analysis: IITA Manual". International Institute of Tropical Agriculture (IITA), Ibadan, Nigeria, 1, p 57, 1978.

[15] Tim Marshall, Composting, available at: https://www.wikihow.com/Make-Homemade-LiquidManure-from-Cow-Pats

[16] C. Chang, T.G. Sommerfeldt and T. Entz, "Rates of soil chemical changes with eleven annual applications of cattle feedlot manure". Canadian Journal of Soil Science, 70, 4, pp 673-681, 1990.

[17] M. Vidali, "Bioremediation: An overview". Pure and Applied Chemistry, 73, 7, pp. 1163-1172, 2001.

[18] U.A. Awode, A. Uzairu, M.L. Balarabe, G.F.S. Harrison and O.J. Okunola, "Assessment of Peppers and Soils for some Heavy metals from Irrigated Farmlands on the banks of River Challawa, Nigeria". Pakistan Journal of Nutrition, 7, 2, pp $244-248,2008$.

[19] N.F. Shaikh and B.D. Gachande, "Influence of Organic and Inorganic Inputs on Soil Physico-Chemical Properties of Jowar Field," International Journal of Science and Research, 4, 10, 2015.

[20] D. Singh, "Integrated Nutrient Management Studies on Yield and Quality of Turmeric (Curcuma longa L.) in an Acid Alfisol". Ph.D Thesis, Chaudhary Sarwan Kumar Himachal Pradesh Krishi Vishvavidyalaya 2007.

[21] S.K. Evelyn, O.S. Jan and A.B. Jeffrey, "Functions of Soil Organic Matter and the Effect on Soil Properties". GRDC Project No CSO 00029

\section{Publish your research article in AIJR journals- \\ $\checkmark \quad$ Online Submission and Tracking \\ $\checkmark$ Peer-Reviewed \\ $\checkmark$ Rapid decision \\ $\checkmark$ Immediate Publication after acceptance \\ $\checkmark$ Articles freely available online \\ $\checkmark$ Retain full copyright of your article. \\ Submit your article at journals.aijr.in}

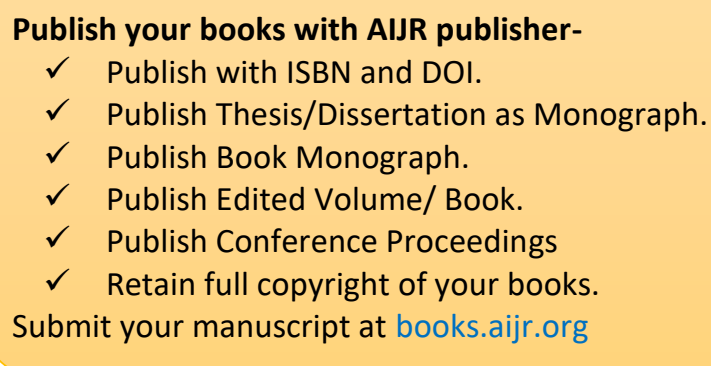

